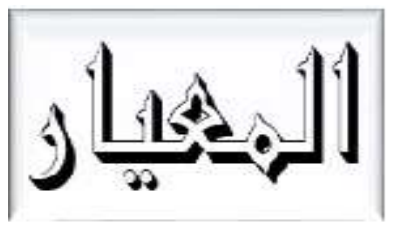

Al Mi'yar

Vol. 3, No. 1, April 2020

P-ISSN: 2620-6749, E-ISSN: 2620-6536

DOI: $10.35931 / a m . v 3 i 1.166$

Disetujui: 16-03-2020

\title{
BENTUK DAN KEDUDUKAN LAFADZ “KAM” DALAM AYAT-AYAT AL-QURAN
}

\author{
Muhammad Sayyidul Arwan', Faizetul Ukhrawiyah² \\ UIN Sunan Kalijaga Yogyakarta \\ email: ${ }^{1}$ ustadz141995@gmail.com, 2Faizahukhrawiyah@gmail.com
}

\begin{abstract}
The languages have a different language formation, because of them make many studies of linguistics, one of them is study of syntax. Study of syintax in Arabic uses Nahwu's knowledge. The method of this research is qualitative descriptive. This research aims to know the form and position of lafadz "Kam" in the verses of the Qur'an. This researh is necessary, when someone is wrong to determine form and position of lafadz, will make error in interpretation and understanding of the text. The result of this research, the form of "lafadz Kam 'in the Qur'an has three forms; the first "Kam Istifhamiyyah" there are six verses, the second "Kam Khobariyyah" there are fifteen verses, and the third have two forms, the form of "Kam Istifhamiyyah" and "Kam Khobariyyah", there are two verses in Qur'an. The lafadz position kam in verses of Qur'an has three positions, namely Mubtada' there are three verses, Maf'ul bih there are fifteen verses, and Dhorof substitute there are three verses.
\end{abstract}

Keywords: Kam Istifhamiyah, Kam Khabariyyah, Al-Qur'an, Nahwu

\section{PENDAHULUAN}

Kajian bahasa sangatlah penting dalam dunia akademisi, karena kajian kebahasaan merupakan batu loncatan pertama dalam memahami suatu sumber ilmu pengetahuan yaitu sebuah teks keilmuan. Salah satu kajian kebahasaan yang sangat mendasar yaitu kajian sintaksis. Kajian sintaksis merupakan kajian yang membicarakan kata dalam hubungannya dengan kata lain, atau unsur-unsur lain sebagai suatu satuan ujaran. ${ }^{1}$ Dalam bahasa Arab,

${ }^{1}$ Abdul Chaer, Linguistik Umum (Jakarta: PT Rineka Cipta, 2012). h. 206. 
Muhammad Sayyidul Arwan \& Faizetul Ukhrawiyah: Bentuk dan Kedudukan Lafadz "Kam" Dalam Ayat-ayat Al Quran

kajian sintaksis memiliki nama ilmu tersendiri yaitu ilmu Nahwu yang berbeda dengan kajian sintaksis dalam bahasa lainnya. Karena setiap bahasa memiliki perbedaan satu dengan lainnya dengan adanya ciri khas yang berbeda-beda. Perbedaan tersebut salah satunya dipengaruhi oleh adanya budaya yang berbeda-beda dari mana bahasa itu muncul.2 Sehingga kajian sintaksis Arab memiliki kajian khusus dengan ilmu Nahwu-nya.

Ilmu Nahwu adalah seni yang mengajarkan tulisan dan pengucapan dalam berbahasa tanpa ada kesalahan. ${ }^{3}$ Makna Nahwu dapat disebut juga sebagai makna struktur (grammar), yang berusaha mengurai makna hingga batas-batas leksikal. Peran leksikal diawali dengan pembatasan level kata, hingga sampai pada batas-batas signifikasi yang mengurai level sosial melalui kalimat dan konteks yang melingkupinya. ${ }^{4}$ Kajian $N a h w u$ sangat penting dipelajari secara utuh dan tuntas, karena dalam kajian ini memiliki karakter yang istimewa disbanding dengan kajian stuktural dalam bahasa lain, yaitu dengan adanya penggunaan I'rab di dalam kajian tersebut. ${ }^{5}$ Kajian tersebut membahas tentang kedudukan atau posisi sebuah kata dalam struktur kalimat, dengan mengatur bunyi akhir kata untuk mendapatkan makna yang dituju dalam pembicaraan. ${ }^{6}$ Karena bunyi akhir sebuah kata menunjukkan posisi kata tersebut dalam sturuktur kalimat, jika bunyi akhir sebuah kata itu salah dalam kalimat, maka pendengar akan salah memahaminya. Adapun tujuan pembelajaran Nahwu tidak lain adalah menjaga lisan dari lahn dan kesalahan pengucapan. ${ }^{7}$ Penguasaan i'rab merupakan salah satu bentuk alat seseorang mampu mencapai tingkatan kefasihah penggunaan bahasa Arab. Karena hal tersebut dapat berimbas pada pemahaman makna yang terkandung dalam teks dan konteks suatu susunan lafadz. ${ }^{8}$

2 Husin Husin dan Hatmiati Hatmiati, "BUDAYA DALAM PENERJEMAHAN BAHASA," Al Mi'yar: Jurnal Ilmiah Pembelajaran Bahasa Arab dan Kebahasaaraban 1, no. 2 (14 Oktober 2018): 39, https://doi.org/10.35931/am.v1i2.43. h. 41. Lihat juga di Hasan, Hasan, Penerjemahan Arab Indonesia Antara Bahasa dan Budaya (Banjarbaru: Atap Buku, 2017). h. 3.

${ }^{3}$ Imil Badi' Ya'qub dan Misal Asy, Al-Mu'jam Al-Mufashol fi Ai-Lighoh wa Al-Adab (Bairut: Darul Ilmi Lil Malayin, t.t.). h. 1237.

4 Mohammad Kholison, Semantik Bahasa Arab: Tinjauan Historis, Teoritik, dan Aplikatif (Sidoarjo: CV Lisan Arabi, 2016). h. 169.

${ }^{5}$ Arif Rahman Hakim, "Mempermudah Pembelajaran Ilmu Nahwu pada abad 20," Jurnal al-Maqoyis 1, no. 1 (t.t.): 1-26. h. 1.

${ }^{6}$ Muhammad Idris Jauhari, Al-Qawaid as-Sharfiyah (Sumenep: Mutiara Press, 2016). h. iv.

7 Jaudat Rikabi, Turuqu Tadris al-Lughah al-'Arabiyah (Damaskus: Dar al-Fikr, 1996). h. 134.

8 Syamsul Hidayat dan Amien Ashiddiqi, “METODE I'RĀB AL-QUR'AN DAN KONVENSIONAL SEBAGAI PEMBELAJARAN BAHASA ARAB BAGI NON ARAB DI PONPES AL MADINAH BOYOLALI," Profetika Jurnal Studi Islam 19, no. 2 (15 Mei 2019): 123-35, https://doi.org/10.23917/profetika.v19i2.8119. h. 125. 
Muhammad Sayyidul Arwan \& Faizetul Ukhrawiyah: Bentuk dan Kedudukan Lafadz "Kam" Dalam Ayat-ayat Al Quran

Pembahasan dalam kajian sintaksis Arab atau ilmu Nahwu sangat bermacam-macam, salah satunya yaitu pembahasan kata atau lafadz Kam. Pembahasan lafadz Kam sangatlah perlu dilakukan, karena lafadz Kam memiliki beberapa bentuk dan kedudukan dalam sebuah struktur kalimat. Ketika seseorang tidak mengetahui bentuk dan kedudukan lafadz Kam dalam sebuah kalimat, maka dia akan salah dalam pengartian, pemaknaan, dan penerjemahan lafadz Kam dalam sebuah kalimat. Hal ini sangat diperlukan bagi para penerjemah teks-teks arab, maupun para peneliti dan pengkaji teksteks arab, terutama pada Al Quran. Maka dalam penelitian ini peneliti akan mengkaji tentang "Bentuk dan Kedudukan Lafadz Kam dalam Al Quran" dengan pendekatan kajian sintaksis Arab atau kajian ilmu Nahwu.

Pembahasan tentang lafadz Kam sangat banyak dalam kajian-kajian ilmu nahwu. Akan tetapi kajian tersebut tidak secara khusus mengkaji lafadz Kam dalam Al Quran, sehingga peneliti akan meneliti secara kusus lafadz Kam dalam Al Quran .Adapun kajian-kajian lafadz Kam yang sudah dilaksanakan seperti halnya pada kitab Nahwu, seperti kitab Alfiyah karya Ibnu Aqil, dan pada Kamus kebahasaan, seperti Al-Mu'jam Al-Mufashol fi Ai-Lighoh wa Al$A d a b$ karya Dr. Imil Badi' Ya'qub dan Dr. Misal Asy, dan juga Al-Mu'jam AlMufashol fi Ai-I'rab karya Al-Ustadz Thohir Yusuf Al-Khotib.

Dalam penelitian ini, peneliti membahasa tentang bentuk-bentuk Kam beserta kedudukannya dalam sebuah kalimat. Hal tersebut dilator belakangi adanya besarnya pengaruh bentuk dan kedudukan Kam jika salah dalam menentukannya. Kesalahan tersebut berimbas terhadap dalam pemaknaan dan pemahaman seseoranga. Terlebih dalam kajian Al Quran yang harus mengetahui bentu dan kedudukan Kam sehingga dapat memahami ayat-ayat secara jelas. Lafadz Kam memiliki dua bentuk yaitu yang berbentuk istifhamiyyah digunakan sebagai kata tanya dalam menanyakan adad atau bilangan. ${ }^{9}$ Makna Kam dalam istifhamiyyah adalah berapa banyak. Bentuk lafadz Kam yang kedua yaitu khabariyyah. Bentuk ini berfungsi sebagai kata kabar atau kata berita, dan Kam khabariyyah memiliki makna كثير (banyak).

Salah satu contoh ayat yang terdapat Kam yaitu pada ayat Qs. Al-Baqoroh: 249.

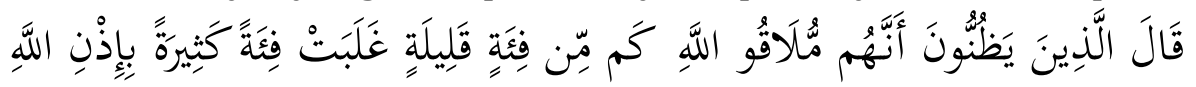

Lafadz Kam pada ayat tersebut berbentuk "Kam khabariyyah" yang berarti banyak. Dan lafadz tersebut berkedudukan menjadi mubtada' atau subjek dalam sebuah kalimat dengan I'rab rafa' mabni sukun.

${ }^{9}$ Abdul Haris, Cepat Membaca Kitab Gundul: Teknik 234, t.t. 
Muhammad Sayyidul Arwan \& Faizetul Ukhrawiyah: Bentuk dan Kedudukan Lafadz "Kam" Dalam Ayat-ayat Al Quran

Dari paparan diatas penelitian ini menggunakan pendekatan dan teori sintaksis Arab atau ilmu Nahwu, yang khusus menbahas tentang lafadz Kam. Pendekatan dan teori tersebut bertujuan untuk menjawab permasalahan dengan rumusan masalah, "Apa saja bentuk dan kedudukan lafadz Kam dalam stuktur ayat-ayat Al-Quran?”. Adapun penelitian ini menggunakan metode deskriptif alanisis dengan cara menjelaskanan dan memaparkan data dan hasil analisisnya.

\section{LANDASAN TEORI}

Kedudukan lafadz Kam pada sebuah struktur kalimat sangat bermacam-macam. Merujuk pada kitab Al-Mu'jam Al-Mufashol fi Ai-I'rab karya Al-Ustadz Thohir Yusuf Al-Khotib, menyebutkan ada delapan bentuk kedudukan lafadz Kam, yaitu : dua berbentuk mubtada', maf'ul bih, maf'ul mutlaq, pengganti dhorof, khobarnya mubtada', khobar untuk fiil naqis dan mudhof ilaih. ${ }^{10}$ Lafadz Kam memiliki banyak arti dan penertian. Menurut bahasa, Kam berarti berapakah, berapa banyaknya dan banyakkah. ${ }^{11}$ Menurut istilah dalam ilmu nahwu, lafadz Kam adalah isim bagi adad (bilangan) yang mubham (misteri). Kam memiliki dua arti : Pertama yaitu istimhamiyyah atau kata tanya, dan kedua yaitu khabariyah atau kata berita yang bermakna banyak. ${ }^{12}$

Lafadz Kam dalam kajian ilmu nahwu memiliki dua bentuk. Dalam landasar teori yang mengambil dari kitab alfiyah, lafadz Kam memiliki dua bentuk, yaitu sebagai kata tanya (Kam istifhamiyyah) dan sebagai kata berita (Kam khabariyyah). ${ }^{13}$ Fungsi "Kam istifhamiyyah" digunakan sebagai kata tanya dalam menanyakan adad atau bilangan. Makna Kam dalam istifhamiyyah adalah berapa banyak. Lafadz Kam memiliki tamyiz yang dibaca nasab.

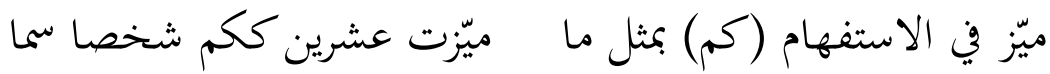

10 Thohir Yusuf Al-Khotib, Al-Mu'jam Al-Mufashol fi Ai-I'rob (Sangqopurah: Al-Haromin, 1991). h. 355.

11 Muhammad Yunus, Kamus Arab-Indonesia (Jakarta: PT. Hidakarya Agung, 1990). h. 382.

12 Ya'qub dan Asy, Al-Mu'jam Al-Mufashol fi Ai-Lighoh wa Al-Adab. h. 1026.

13 Bahrun Abu Bakar, Terjemahan Alfiyah Syarah Ibnu 'Aqil (Bandung: Penerbit Sinar Baru Algensindo, 2013). h. 820. 
Muhammad Sayyidul Arwan \& Faizetul Ukhrawiyah: Bentuk dan Kedudukan Lafadz "Kam" Dalam Ayat-ayat Al Quran

Tamyiz-kan lah dalam istifham lafaz Kam, seperti anda mentamyiz-kan lafaz 'isyriina, seperti: Kam syahshan samaa (Banyak orang yang berpekerti luhur). ${ }^{14}$

Teori alfiyah menyatakan, bahwa lafadz setelah Kam menadi tamyiz, seperti lafadz شخصا (syahsan). Lafadz syahsan ber I'rab nasab dengan fathah, karena lafadz syahsan berkedudukan menjadi tamyiz. Lafadz yang menjadi tamyiznya Kam bisa dibuang dengan syarat, lafadz tersebut sudah ada petunjuk yang mengisyaratkan keberadaannya, contoh: كم استريت هذا ؟ (berapa Kamu telah beli barang ini?) makna yang diinginkan كم روبيّة اشتريت هذا ؟ روبيّة (berapa rupiah Kamu telah beli barang ini?). lafadz) dibuang karena sudah bisa diketahui yaitu matauang dan ditunjukkan dengan ucapan pembelian barang tersebut.

$$
\text { وأجز ان بترّه (من) مضمرا إن و ليت (كم) حرف جرّ مظهرا }
$$

Diperkenankan men-jer-kan tamyiz dengan min yang di

sembunyikan, apabila Kam diikuti oleh huruf jer yang ditampakkan. ${ }^{15}$

Kam bisa diawali dengan huruf jer. Jika Kam di dahului dengan huruf jeh, maka lafadz setelahnya dibaca jer. Karena ada lafadz min yang tersimpan. Dan I'rab lafadz setelah Kam yang semula tamyiz dibaca nasab, maka akan menjadi jer dengan lafadz min yang tersimpan. Contoh: بكم رجلِ حضرت (Dengan berapa orang Kamu datang?), bentuk lengangkanya adalah بكم من (Dengan berapa orang Kamu datang?). lafadz rojulin dibaca jer karena kemasukan lafadz min yang tidak nampak atau dinampakkan.

Kam selain berfungsi sebagai kata tanya. Kam juga memiliki fungsi sebagai Kam khabariyyah yaitu sebagai kata kabar atau kata berita, dan Kam

14 Bahrun Abu Bakar, Terjemahan Alfiyah.... h. 820.

15 Bahrun Abu Bakar, Terjemahan Alfiyah...... h. 820. 
Muhammad Sayyidul Arwan \& Faizetul Ukhrawiyah: Bentuk dan Kedudukan Lafadz "Kam" Dalam Ayat-ayat Al Quran

khabariyyah memiliki makna كثير (banyak). Landasan teori dalam alfiyah memiliki beberapa kaida tatacara pembacaan lafadz setelah lafadz Kam.
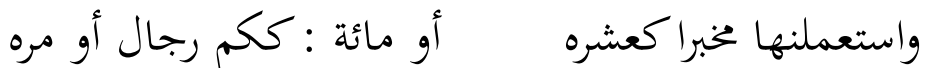

Gunakan Kam sebagai kata berita, seperti lafaz 'asyarah atau mi'ah, sebagaimana dalam contoh: Kam rijalin (Banyak laki-laki) atau Kam marrah (Banyak waktu). ${ }^{16}$

Teori kaidah dalam alfiyah ini menunjukkan fungsi Kam sebagai kata berita. Lafadz setelah lafadz Kam bisa berbentuk jama' dan mufrod dan berI'rab jer. Contoh : رجال كم رجال (banyak laki-laki), lafadz رجال (rijalin) dibaca jer karena lafadz asli dari kalimat tersebut terdapat lafadz min. Bentuk lengkapnya adalah كثير من رجال (banyak laki-laki).

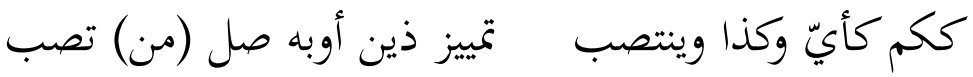

Sama dengan lafaz Kam, yaitu ka-ayyin dan kadzaa, tamyiz kedua-nya di-nasab-kan, atau masukkanlah kepadanya huruf min, maka itu tetap benar. ${ }^{17}$

Lafadz-lafadz selai Kam yang memiliki hukum sama seperti Kam, antara lain adalah lafadz ka-ayyin dan kadzaa. Kedua lafadz ini hanya memiliki fungsi yang sama pada lafadz Kam khabariyyah yang bermakna كثير (banyak). Lafadz setelah lafadz ka-ayyin dan kadzaa menjadi tamyiz. Tamyiz kedua lafadz tersebut bisa dibaca dua macam, yaitu dengan I'rab nasab dan jer dengan min. Tetepi lebih banyak yang menggunakan bacaan jer dengan lafadz min. Contoh كأيّ من رجال ذهب معه : (berapa banyak laki-laki yang pergi bersamanya). رجال Lafadz رجال 
Muhammad Sayyidul Arwan \& Faizetul Ukhrawiyah: Bentuk dan Kedudukan Lafadz "Kam" Dalam Ayat-ayat Al Quran

(rijalin) bisa dibaca nasab dengang syarat membuang lafadz min. Lafadz رجال (rijalin) memiliki dua macam bacaan.

I'rab lafadz Kam dilihat dari kedudukan lafadz Kam dalam kaliamat. Dalam Kitab Al-Mu'jam Al-Mufashol fi Ai-I'rab, karya Al-Ustadz Thohir Yusuf Al-Khotib menyebutkan ada delapan bentuk kedudukan I'rab, yaitu : dua berbentuk mubtada', maf'ul bih, maf'ul mutlaq, pengganti dhorof, khobarnya mubtada', khobar untuk fiil naqis dan mudhof ilaih. ${ }^{18}$ Macam-macam kedudukan lafadz Kam dalam kalimat, sebagai berikut :

\section{Mubtada'}

Lafadz Kam berkedudukan menjadi mubtada'. Ketika setelah keduanya berbentuk fiil lazim atau fiil muta'addi yang mengfungsikan mafulnya. Contoh كم عالما يقوم علي المنبار؟ (berapa orang alim yang sedang berdiri di mimbar?). lafadz berkedudukan menjadi mubtada', karena setelah lafald Kam dan tamyiznya berbentuk fiil lazim yaitu lafadz يقوم (berdiri) yang tidak memerlukan obyek, beri'rab rafa' karena tidak dimasuki āmil nawāsib dan āmil jawāzim dan beralamat dummah.

\section{Mubtada'}

Kam dan tamyisnya berkedudukan menjadi mubtada'. Ketika setelah אم صالحا في المسجد؟ :keduanya berbentuk dhorof atau jer majrur. Contoh (berapa orang yang sholih yang di dalam masjid?). lafadz صم صالحا berkedudukan menjadi mubtada'. lafadz كم (Kam istifhamiyyah) mabni sukun, lafadz صالحا berkedudukan menjadi tamyiz yang berI'rab nasab dengan alamat nasabnya fathah, karena isim mufrod. Lafadz في المسجد berkedudukan menjadi

${ }^{18}$ Al-Khotib, Al-Mu'jam Al-Mufashol fi Ai-I'rob. h. 355. 
Muhammad Sayyidul Arwan \& Faizetul Ukhrawiyah: Bentuk dan Kedudukan Lafadz "Kam" Dalam Ayat-ayat Al Quran

khobar yang berbentuk jer majrur. Lafadz في (huruf jer) mabni sukun dan lafadz المسجد berI'rab jer, dengan alamat jernya kasroh, karena isim mufrod.

\section{Maf'ul Bih}

Kam dapat berkedudukan menjadi maf'ul bih ketika terdapat fiil mutaaddi yang jatuh setelah Kam dan tamyiznya, dan fiil mutaaddi tersbut tidak mengfungsikan mafulnya. Contoh: كم كتابا كتبت (berapa kitab yang telah Kamu tulis?). Lafadz كم berkedudukan menjadi maf'ul bih, karena setelah lafadz Kam dan tamyiznya adalah fiil mutaaddi yang tidak mengfungsikan maf'ul bihnya.

\section{Maf'ul Mutlaq}

Lafadz Kam berkedudukan menjadi maf'ul mutlaq. Ketika tamyiz keduanya terbentuk dari fiilnya atau yang berma'na sama dengan fiilnya. Contoh : كم قرأة قرأت الكتاب؟ (berapa kali Kamu membaca kitab ini?). lafadz berkedudukan menjadi maf'ul mutlaq. Karena tamyiznya terbentuk dari fiilnya, yaitu lafadz قرأة berbentuk masdar dari fiil lafadz قرأ Lafadz قرأة menjadi tamyiznya lafadz قرأ dan lafadz.

\section{Pengganti Dhorof}

Kedudukan lafadz Kam bisa menjadi kedudukan pengganti dhorof. Ketika tamyiznya berbentuk dhorof yaitu dhorof zaman (keterangan waktu) atau dhorof makan (keterangan tempat). Contoh: كم ساعة سفرت؟ (berapa jam Kamu berjalan?). lafadz 5 berkedudukan menjadi pengganti dhoroh yaitu ساعة. Karena tamyiznya berbentuk dhorof zaman (keterangan waktu).

\section{Khobarnya Mubtada'}

Kam berkedudukan menjadi khobar dengan syarat. Ketika terdapat isim yang berada setelah tamyiznya berbentuk isim ma'rifah atau isim yang 
Muhammad Sayyidul Arwan \& Faizetul Ukhrawiyah: Bentuk dan Kedudukan Lafadz "Kam" Dalam Ayat-ayat Al Quran

dimudohfkan kepada isim ma'rifah. Contoh: كم رجلا غلامك؟ (berapa orang budakmu?). lafadz berkedudukan menjadi khobarnya mubtada'. karena lafadz setelah tamyiznya berbertuk isim yang dimudhofkan kepada isim ma'rifah.

\section{Khobar untuk Fiil Naqis}

Kam berkedudukan menjadi khobar untuk fiil naqis atau khobarnya. Fiil naqis adalah fiil yang masuk pada mubtada' dan khobar dengan beramal merafa'kan isimnya dan menasabkan khobarnya. ${ }^{19}$ Fiil nakis memiliki dua bagian, yaitu: kana beserta teman-temannya, dan kada beserta temantemannya. Contoh: كم مرأة كانت القائمة امام الفصل؟ berapa perempuan yang sudah berdiri didepan kelas?). Lafadz كم مر menjadi isimnya fiil naqis yaitu lafadz كان yang beramal merafa'kan isimnya dan menasabkan khobarnya.

\section{Mudhof Ilaih}

Lafadz Kam dapat berkedudukan menjadi mudhof ilaih dengan syarat, Kam dan tamnyiznya berada setelah isim. Contoh: مساعدة كم فقيرا قدّمت؟ (berapa orang fakir yang telah Kamu beri pertolongan?). Lafadz كم berkedudukan menjadi mudhof ilaih karena jatuh setelah isim yaitu lafadz مساعدة yang menjadi mudhof.

\section{ANALISIS LAFADZ KAM DALAM AYAT-AYAT AL-QURAN}

Lafadz-lafadz Al Quran memilki nilai yang tinggi dalam berbagai hal. Dalam keilmuan kebahasaan, menjadikan Al Quran sebagai sumber utama dan pedoman dalam pembuatan kaidah-kaidah kebahasaan. Ilmu Nahwu atau ilmu sintaksis Arab merupkan ilmu yang membahas tentang kaidah dan penerapan I'rab dalam sebuah kedudukan kata atau lafadz pada sebuah stuktur kalimah.

${ }^{19}$ Al-Khotib. h. 946. 
Muhammad Sayyidul Arwan \& Faizetul Ukhrawiyah: Bentuk dan Kedudukan Lafadz "Kam" Dalam Ayat-ayat Al Quran

Dalam pembahasan ilmu Nahwu terdapat banyak pembahasan, salah satunya adalah pembahasan bentuk dan kedudukan lafadz Kam dalam sebuah tataran kalimat.

Dalam Al Quran lafadz Kam terdapat pada 21 ayat yang terhimpun dalam 28 surat, yaitu: Surat Al-Baqoroh (Ayat 211, 249, 259), Surat Al-An'am (Ayat 6), Surat Al-A'raf (Ayat 4), Surat Al-Israa (Ayat 17), Surat Al-Kahf (Ayat 19), Surat Maryam (Ayat 74, 98), Surat Taa-Haa (Ayat 128), Surat Al-Ambiyaa (Ayat 11), Surat Al-Muminoon (Ayat 112), Surat Ash-Shu'araa (Ayat 7), Surat AlQasas (Ayat 58), Surat As-Sajda (Ayat 26), Surat Yaseen (Ayat 31), Surat Saad (Ayat 3), Surat Az-Zukhruf (Ayat 6), Surat Ad-Dukhaan (Ayat 25), Surat Qaaf (Ayat 36), dan Surat An-Najm (Ayat 26).

Bentuk lafadz Kam dalam Al Quran ada dua, yaitu bentuk "Kam Istifhamiyyah" yang berfungsi sebagai pertanyaan dan "Kam Khobariyah" yang berfungsi sebagai kabar berita. Lafadz Kam dalam Al Quran yang bentuk "Kam Istifhamiyyah" terdapat pada ayat-ayat sebagai berikut: Surat Al-Baqoroh (Ayat 211), Surat Al-Baqoroh (Ayat 259), Surat Al-An'am (Ayat 6), Surat Al-Kahf (Ayat 19), Surat Al-Muminoon (Ayat 112), dan Surat Yaseen (Ayat 31). Adapun lafadz Kam dalam Al Quran yang bentuk "Kam Khobariyya" terdapat pada ayat-ayat sebagai berikut: Surat Al-Baqoroh (Ayat 249), Surat Al-An'am (Ayat 6), Surat Al$A^{\prime}$ raf (Ayat 4), Surat Al-Israa (Ayat 17), Surat Maryam (Ayat 74), Surat Maryam (Ayat 98), Surat Taa-Haa (Ayat 128), Surat Al-Ambiyaa (Ayat 11), Surat AshShu'araa (Ayat 7), Surat Al-Qasas (Ayat 58), Surat As-Sajda (Ayat 26), Surat Yaseen (Ayat 31), Surat Saad (Ayat 3), Surat Az-Zukhruf (Ayat 6), Surat AdDukhaan (Ayat 25), Surat Qaaf (Ayat 36), dan Surat An-Najm (Ayat 26). Dan adapun lafadz Kam dalam Al Quran yang memiliki dua bentuk antara "Kam Istifhamiyyah" dan "Kam Khobariyya" terdapat pada Surat Al-An'am (Ayat 6) dan Surat Yaseen (Ayat 31).

Lafadz Kam ditinjau dari segi kedudukannya dalam sebuah ayat-ayat Al Quran terdapat pada tiga kedudukan, yaitu Mubtada', Maf'ul bih dan Pengganti Dhorof.

\section{Mubtada'}

Lafadz Kam berkedudukan menjadi mubtada' berl'rab makhal rafa' dan beralamat mabni sukun. Ayat-ayat Al Quran yang berkedudukan mubtada', sebagai berikut: Surat Al-Baqoroh ayat 249, Surat Al-A'raf ayat 4, dan Surat AnNajm ayat 26. 
Muhammad Sayyidul Arwan \& Faizetul Ukhrawiyah: Bentuk dan Kedudukan Lafadz “Kam” Dalam Ayat-ayat Al Quran

Tabel. 1 (Surat Al-Baqoroh: 249)

\begin{tabular}{|c|c|c|c|c|}
\hline Lafadz & Kedudukan & I'rab & $\begin{array}{c}\text { Alamat } \\
\text { I'rab }\end{array}$ & Keterangan \\
\hline كَم & Mubtada' & $\begin{array}{l}\text { Makhal } \\
\text { rafa' }\end{array}$ & $\begin{array}{l}\text { Mabni } \\
\text { sukun }\end{array}$ & Kam khabariyyah \\
\hline هِّن فِيَّةٍ & $\begin{array}{l}\text { Tamyiz } \\
\text { Kam }\end{array}$ & $\begin{array}{l}\text { Makhal } \\
\text { nasab }\end{array}$ & & Jer majrur \\
\hline غَلَبَتَتْ فِئََةً & $\begin{array}{l}\text { Khobar } \\
\text { Kam }\end{array}$ & $\begin{array}{l}\text { Makhal } \\
\text { rafa' }\end{array}$ & & Jumlah fi'liyyah \\
\hline
\end{tabular}

Dalam tabel. 1 menjelaskan tentang bentuk Kam dan kedudukannya pada ayat 249 surat al-Baqoroh. Kam pada ayat tersebut berbentuk Kam Khabariyyah yang berarti "banyak" tidak berfungsi sebagai pertanyaan. Kedudukan Kam tersebut sebagai Muntada' atau sebagai subjek dari sebuah kalimat. Dengan berkedudukan menjadi mubtada', maka Kam tersebut memiliki I'rab Mahal rafa' kerena lafadz Kam tersebut Mabni sukun. Lafadz Kam sejatinya memiliki tamyiz, pada ayat tersebut yang menjadi tamyiz yaitu

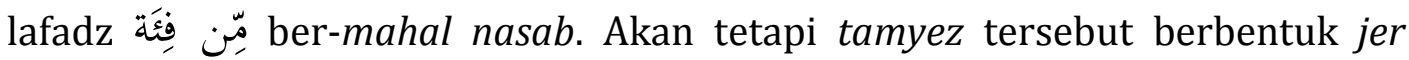
majrur. Bentukan jer majrur tersebut adalah terdiri dari huruf jer yaitu مِّن dan lafadz yang di-jer-kan yaitu Aِ Adapun khobar atau predikat pada ayat

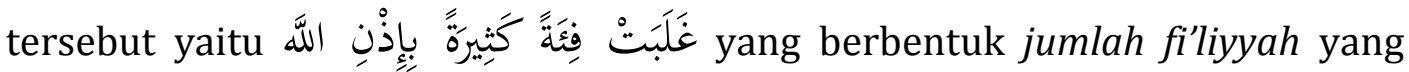
terdiri dari fiil, fail dan keterangan.

Tabel. 2 (Surat Al-A'raf : 4)

\begin{tabular}{|c|c|c|c|c|}
\hline \multicolumn{5}{|c|}{ 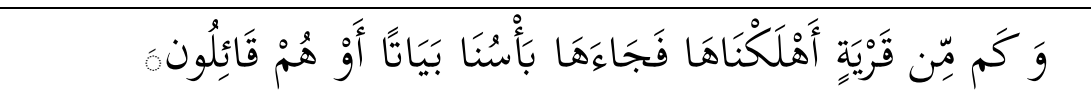 } \\
\hline Lafadz & Kedudukan & I'rab & $\begin{array}{c}\text { Alamat } \\
\text { I'rab }\end{array}$ & Keterangan \\
\hline
\end{tabular}


Muhammad Sayyidul Arwan \& Faizetul Ukhrawiyah: Bentuk dan Kedudukan Lafadz "Kam" Dalam Ayat-ayat Al Quran

\begin{tabular}{|c|c|c|c|c|}
\hline كَمْ & Mubtada' & $\begin{array}{l}\text { Makhal } \\
\text { rafa' }\end{array}$ & $\begin{array}{l}\text { Mabni } \\
\text { sukun }\end{array}$ & Kam khabariyyah \\
\hline هِّن قَرَيٍَِِ & $\begin{array}{l}\text { Tamyiz } \\
\text { Kam }\end{array}$ & $\begin{array}{l}\text { Makhal } \\
\text { nasab }\end{array}$ & & Jer majrur \\
\hline أَهْلَكْنَاهَا & $\begin{array}{l}\text { Khobar } \\
\text { Kam } \\
\end{array}$ & $\begin{array}{l}\text { Makhal } \\
\text { rafa' }\end{array}$ & & Jumlah fi'liyyah \\
\hline
\end{tabular}

Tabel. 2 tersebut menjelaskan tentang bentuk Kam yang berbentuk Kam Khabariyyah dan kedudukannya sebagai Mubtada' dalam ayat 4 surat AlA'raf. Kam pada ayat tersebut menjadi mubtada' dengan mahal rafa' karena mabni sukun. Adapun tamyiz-nya yaitu lafadz مِّرن قَرَيْة yang tersusun dari huruf jer dan lafadz yang di-jer-kan. Khobar lafadz Kam berbentuk dari jumlah fi'liyyah yang terdiri dari fiil dan fail, yaitu pada lafadz أَهْلَكْنَاهَا.

Tabel. 3 (Surat An-Najm: 26)

\begin{tabular}{|c|c|c|c|c|}
\hline \multicolumn{5}{|c|}{ 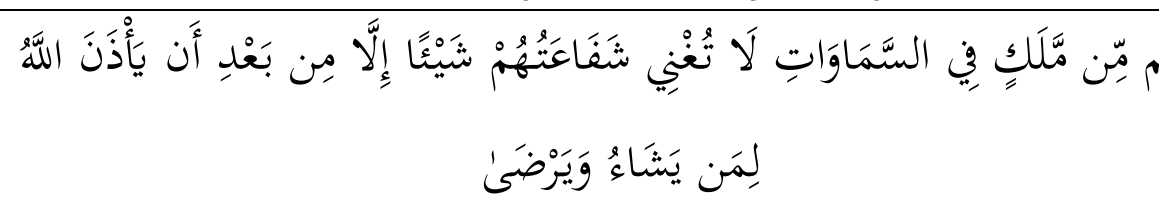 } \\
\hline Lafadz & Kedudukan & I'rab & $\begin{array}{c}\text { Alamat } \\
\text { I'rab }\end{array}$ & Keterangan \\
\hline كَ & Mubtada' & $\begin{array}{l}\text { Makhal } \\
\text { rafa' }\end{array}$ & $\begin{array}{l}\text { Mabni } \\
\text { sukun }\end{array}$ & Kam khabariyyah \\
\hline هِّن مِنَلَكِ & $\begin{array}{l}\text { Tamyiz } \\
\text { Kam }\end{array}$ & $\begin{array}{l}\text { Makhal } \\
\text { nasab }\end{array}$ & & Jer majrur \\
\hline السِّمَاوَاتِ & $\begin{array}{l}\text { Khobar } \\
\text { Kam }\end{array}$ & $\begin{array}{l}\text { Makhal } \\
\text { rafa' }\end{array}$ & & Jer majrur \\
\hline
\end{tabular}

Dalam tabel. 3 merupakan penjelasan lafadz Kam pada Qs. An-Najm: 26. Kam tersebut berbentuk Kam Khabariyyah yang berarti "banyak" tidak berarti "berapa". Kedudukan Kam pada ayat tersebut menjadi muntada' yang bermahal rafa' dengan mabni sukun. Tamyiz pada ayat tersebut adalah 
Muhammad Sayyidul Arwan \& Faizetul Ukhrawiyah: Bentuk dan Kedudukan Lafadz "Kam" Dalam Ayat-ayat Al Quran

yang berbentuk jer majrur. Adapun khobar-nya yaitu lafadz yang بي السَّمَاوَاتِ yan berbentuk shibih jumlah yaitu jer majrur.

\section{Maful bih}

Lafadz Kam berkedudukan menjadi maf'ul bih berl'rab makhal nasab dan beralamat mabni sukun. Ayat-ayat Al Quran yang berkedudukan sebagai maf'ul bih sebagai berikut : Surat Al-Baqoroh Ayat 211, Surat Al-An'am Ayat 6, Surat Al-Israa Ayat 17, Surat Maryam Ayat 74, Surat Maryam Ayat 98, Surat Taa-Haa Ayat 128, Surat Al-Ambiyaa Ayat 11, Surat Ash-Shu'araa Ayat 7, Surat Al-Qasas Ayat 58, Surat As-Sajda Ayat 26, Surat Yaseen Ayat 31, Surat Saad Ayat 3, Surat Az-Zukhruf Ayat 6, Surat Ad-Dukhaan Ayat 25, dan Surat Qaaf Ayat 36.

Tabel. 4 (Surat Al-Baqoroh: 211)

\begin{tabular}{|c|c|c|c|c|}
\hline \multicolumn{5}{|c|}{ 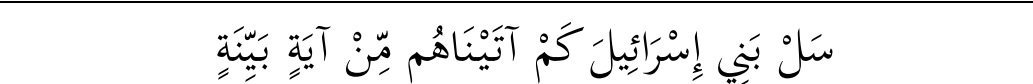 } \\
\hline lafadz & Kedudukan & I'rab & $\begin{array}{c}\text { Alamat } \\
\text { I'rab }\end{array}$ & Keterangan \\
\hline كَنْ & $\begin{array}{l}\text { Maf'ul bih } \\
\text { kedua dari } \\
\text { lafadz } \\
\text { آتَيَنَاهُم }\end{array}$ & $\begin{array}{l}\text { Makhal } \\
\text { nasab }\end{array}$ & $\begin{array}{l}\text { Mabni } \\
\text { sukun }\end{array}$ & $\begin{array}{l}\text { Kam } \\
\text { istifamiyyah }\end{array}$ \\
\hline آتَيْنَاهُمُم & $\begin{array}{l}\text { Maf'ul bih } \\
\text { dari lafadz } \\
\text { سََ. }\end{array}$ & $\begin{array}{l}\text { Makhal } \\
\text { nasab }\end{array}$ & & $\begin{array}{l}\text { Jumlah } \\
\text { fi'liyyah, } \\
\text { tersusun dari } \\
\text { fiil, fail dan } \\
\text { maf'ul bih } \\
\text { pertama }\end{array}$ \\
\hline مَّنْ آيَةٍ & $\begin{array}{l}\text { Tamyiz } \\
\text { dari lafadz } \\
\text { ك́ }\end{array}$ & $\begin{array}{l}\text { Makhal } \\
\text { nasab }\end{array}$ & & Jer majrur \\
\hline
\end{tabular}


Muhammad Sayyidul Arwan \& Faizetul Ukhrawiyah: Bentuk dan Kedudukan Lafadz "Kam" Dalam Ayat-ayat Al Quran

Tabel. 4 menjalasakan tentang bentuk dan kedudukan lafadz Kam dalam Qs. Al-Baqoroh: 211. Bentuk lafadz Kam tersebut adalah Kam Istifhamiyyah, yaitu lafadz Kam yang berfungsi sebagai pertanyaan "berapa banyak". Kedudukannya sebagai maf'ul bih kedua dari fiil fail آتيَنْنَا, yang memiliki maf'ul bih pertama yaitu dhomir هُم Adapun I'rab-nya yaitu mahal nasab dengan bentuk mabni sukun. Adapun tamyiz Kam yaitu آيٍَ berbentuk jer majrur, yang terdiri dari huruf jer بِّن dan lafadz yang dibaca jer yaitu آيَية

Tabel. 5 (Surat Al-An'am: 6)

\begin{tabular}{|c|c|c|c|c|}
\hline \multicolumn{5}{|c|}{ 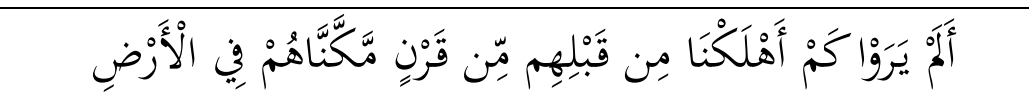 } \\
\hline lafadz & Kedudukan & I'rab & $\begin{array}{c}\text { Alamat } \\
\text { I'rab }\end{array}$ & Keterangan \\
\hline كَمْ & $\begin{array}{l}\text { Maf'ul bil } \\
\text { untuk } \\
\text { lafadz } \\
\text { أَهْiَ }\end{array}$ & $\begin{array}{l}\text { Makhal } \\
\text { nasab }\end{array}$ & $\begin{array}{l}\text { Mabni } \\
\text { sukun }\end{array}$ & $\begin{array}{l}\text { Kam } \\
\text { khabariyyah } \\
\text { atau Kam } \\
\text { istifhamiyyah }\end{array}$ \\
\hline قَبَنْلِهِم & $\begin{array}{l}\text { Tamyiznya } \\
\text { Kam }\end{array}$ & $\begin{array}{l}\text { Makhal } \\
\text { nasab }\end{array}$ & & Jer majrur \\
\hline
\end{tabular}

Tabel. 5 menjelaskan tentang bentuk dan kedudukan lafadz Kam dalam Qs. Al-An'an: 6. Lafadz Kam pada ayat tersebut berbentuk dua macam, yaitu Kam khabariyyah yang berarti "banyak", dan Kam istifhamiyyah yang berarti berepa banyak. Lafadz tersebut berkedudukan sebagai maf'ul bih dari lafadz

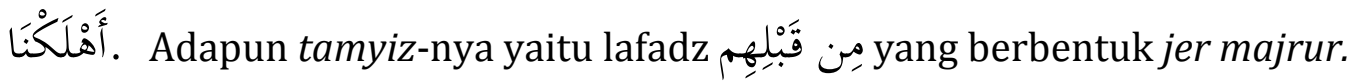

\section{Tabel. 6 (Surat Al-Israa: 17)}


Muhammad Sayyidul Arwan \& Faizetul Ukhrawiyah: Bentuk dan Kedudukan Lafadz "Kam" Dalam Ayat-ayat Al Quran

\begin{tabular}{|c|c|c|c|c|}
\hline \multicolumn{5}{|c|}{ 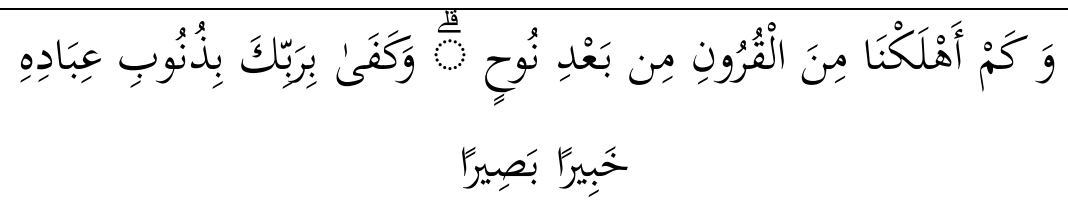 } \\
\hline lafadz & Kedudukan & I'rab & $\begin{array}{c}\text { Alamat } \\
\text { I'rab }\end{array}$ & Keterangan \\
\hline كَمْ & $\begin{array}{l}\text { Maf'ul bih } \\
\text { untuk } \\
\text { lafadz } \\
\text { أَهْلَكْنَ }\end{array}$ & $\begin{array}{l}\text { Makhal } \\
\text { nasab }\end{array}$ & $\begin{array}{l}\text { Mabni } \\
\text { sukun }\end{array}$ & $\begin{array}{l}\text { Kam } \\
\text { khobaiyyah }\end{array}$ \\
\hline الَْقُرُونَ & $\begin{array}{l}\text { Tamyiz } \\
\text { Kam }\end{array}$ & $\begin{array}{l}\text { Makhal } \\
\text { nasab }\end{array}$ & & Jer majrur \\
\hline
\end{tabular}

Dalam tabel. 8 menjelaskan tentang bentuk dan kedudukan Kam pada Qs. Al-Israa: 17. Bentuk dari Kam tersebut adalah Kam Khabariyyah. Kam tersebut berkedudukan sebagai maful bih atau objek dari lafadz أَهْلَكْكْ . Sehingga Kam memiliki I'rab mahal nasab dengan tanda mabni sukun. Adapun tamyiz dari lafadz Kam tersebut adalah مَنَ الْقُرُون yang berbentuk jer majrur.

Tabel. 7 (Surat Maryam: 74)

\begin{tabular}{|c|c|c|c|c|}
\hline \multicolumn{5}{|c|}{ 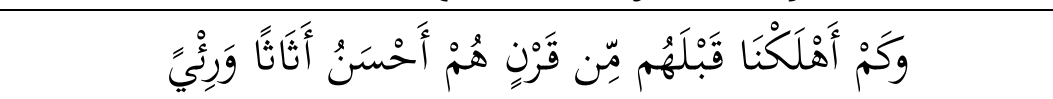 } \\
\hline Lafadz & Kedudukan & I'rab & $\begin{array}{c}\text { Alamat } \\
\text { I'rab }\end{array}$ & Keterangan \\
\hline كَمْ & $\begin{array}{l}\text { Maf'ul bih } \\
\text { lafadz } \\
\text { أَهْلَكْنَا }\end{array}$ & $\begin{array}{l}\text { Makhal } \\
\text { nasab }\end{array}$ & $\begin{array}{l}\text { Mabni } \\
\text { sukun }\end{array}$ & $\begin{array}{l}\text { Kam } \\
\text { khabariyyah }\end{array}$ \\
\hline هِنْ قَرْن & $\begin{array}{l}\text { Tamyiz } \\
\text { Kam }\end{array}$ & $\begin{array}{l}\text { Makhal } \\
\text { nasab }\end{array}$ & & Jer majrur \\
\hline
\end{tabular}

Pada tabel. 7 menjelaskan tentang bentuk dan kedudukan lafadz Kam dalam Qs. Maryam: 74. Dalam ayat tersebut lafadz Kam memiliki bentuk Kam 
Muhammad Sayyidul Arwan \& Faizetul Ukhrawiyah: Bentuk dan Kedudukan Lafadz "Kam" Dalam Ayat-ayat Al Quran

Khabariyyah dangan kedudukan sebagai maful bih dari lafadz أَهْلَكْنَا Adapun tamyiz-nya yaitu lafadz قِمَن قَرْن yang berbentuk jer majrur, yang terdiri dari huruf jer dan isim yang di-jer-kan yaitu قَّنْ.

Tabel. 8 (Surat Maryam: 98)

\begin{tabular}{|c|c|c|c|c|}
\hline Lafadz & Kedudukan & I'rab & $\begin{array}{l}\text { Alamat } \\
\text { I'rab }\end{array}$ & Keterangan \\
\hline كَمْ & $\begin{array}{l}\text { Maf'ul bih } \\
\text { lafadz } \\
\text { أَهْلَكَنْاَ }\end{array}$ & $\begin{array}{l}\text { Makhal } \\
\text { nasab }\end{array}$ & $\begin{array}{l}\text { Mabni } \\
\text { sukun }\end{array}$ & $\begin{array}{l}\text { Kam } \\
\text { khabariyyah }\end{array}$ \\
\hline هِّن قَرْن & $\begin{array}{l}\text { Tamyiz } \\
\text { Kam }\end{array}$ & $\begin{array}{l}\text { Makhal } \\
\text { nasab }\end{array}$ & & Jer majrur \\
\hline
\end{tabular}

Tabel. 8 menjelaskan tentang Kam yang terdapat pada Qs. Maryam: 98. Lafadz Kam pada ayat tersebut berbentuk Kam Khabariyyah yang berarti “banyak”. Kedudukan Kam menjadi maf'ul bih atau objek dari lafadz أَهْلَكْنَا . Adapun tamyiz dari lafadz Kam yaitu lafadz قِّنَ قِّن yang berbentuk jer majrur.

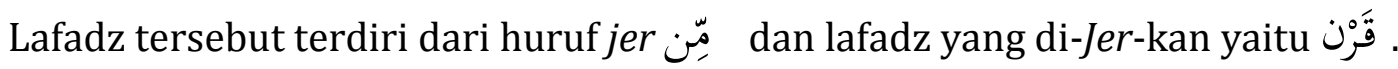

Tabel. 9 (Surat Taa-Haa: 128)

\begin{tabular}{|c|c|c|c|c|}
\hline Lafadz & Kedudukan & I'rab & $\begin{array}{c}\text { Alamat } \\
\text { I'rab }\end{array}$ & Keterangan \\
\hline كَمْ & $\begin{array}{l}\text { Maf'ul bih } \\
\text { lafadz } \\
\text { أَهْكَكْنَ }\end{array}$ & $\begin{array}{l}\text { Makhal } \\
\text { nasab }\end{array}$ & $\begin{array}{l}\text { Mabni } \\
\text { sukun }\end{array}$ & $\begin{array}{l}\text { Kam } \\
\text { khabariyyah }\end{array}$ \\
\hline
\end{tabular}


Muhammad Sayyidul Arwan \& Faizetul Ukhrawiyah: Bentuk dan Kedudukan Lafadz "Kam" Dalam Ayat-ayat Al Quran

\begin{tabular}{|c|c|c|c|}
\hline الِّْرُنَ & $\begin{array}{l}\text { Na'at } \\
\text { tamyiznya } \\
\text { Kam yaitu } \\
\text { قُرُن }\end{array}$ & $\begin{array}{l}\text { Makhal } \\
\text { nasab }\end{array}$ & Jer majrur \\
\hline
\end{tabular}

Dalam tabel. 9 menjelaskan tentang bentuk dan kedudukan Kam dalam Qs. Taa-Haa: 128. Kam pada ayat tersebut berbentuk kam Khabariyyah yang berarti "banyak". Kedudukan Kam pada ayat tersebut sebagai maf'ul bih atau objek dari lafadz أَهْلَكَنْنا. Adapun tamyiz dari lafadz Kam yaitu lafadz قُرِّن yang

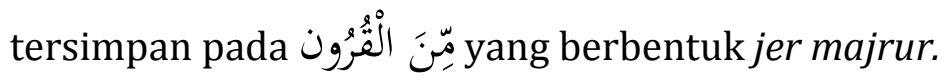

Tabel. 10 (Surat Al-Ambiyaa: 11)

\begin{tabular}{|c|c|c|c|c|}
\hline \multicolumn{5}{|c|}{ 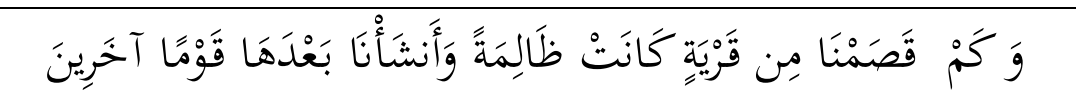 } \\
\hline Lafadz & Kedudukan & I'rab & $\begin{array}{c}\text { Alamat } \\
\text { I'rab }\end{array}$ & Keterangan \\
\hline كَمْ & $\begin{array}{l}\text { Maf'ul bih } \\
\text { lafadz } \\
\text { قَصَمَفْنَ }\end{array}$ & $\begin{array}{l}\text { Makhal } \\
\text { nasab }\end{array}$ & $\begin{array}{l}\text { Mabni } \\
\text { sukun }\end{array}$ & $\begin{array}{l}\text { Kam } \\
\text { khabariyyah }\end{array}$ \\
\hline مِن قَرَيَّة & $\begin{array}{l}\text { Tamyiz } \\
\text { Kam }\end{array}$ & $\begin{array}{l}\text { Makhal } \\
\text { nasab }\end{array}$ & & Jer majrur \\
\hline
\end{tabular}

Tabel. 10 menjelaskan tentang bentuk dan kedudukan lafadz Kam pada ayat 11 Qs. Al-Ambiyaa. Bentuk Kam pada ayat tersebut adalah bentuk kam khabariyah yang ber-makhal nasab, karena berkedudukan menjadi maf'ul bih dari jumlah fi'liyyah lafadz قَصَمَaْ. Adapun tamyiz dalam ayat tersebut adalah lafadz مِن قَرَيِِْ yang berbentuk jer majrur dari huruf jer مِن dan lafadz yang dibaca jer yaitu قَرَيَّة .

Tabel. 11 (Surat Ash-Shu'araa: 7) 
Muhammad Sayyidul Arwan \& Faizetul Ukhrawiyah: Bentuk dan Kedudukan Lafadz "Kam" Dalam Ayat-ayat Al Quran

\begin{tabular}{|c|c|c|c|c|}
\hline \multicolumn{5}{|c|}{ 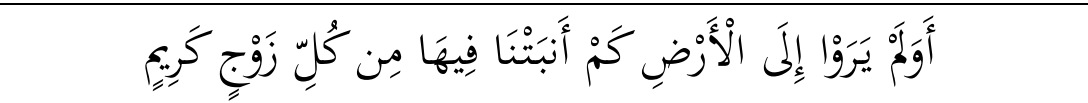 } \\
\hline Lafadz & Kedudukan & I'rab & $\begin{array}{c}\text { Alamat } \\
\text { I'rab }\end{array}$ & Keterangan \\
\hline كَمْ & $\begin{array}{l}\text { Maf'ul bih } \\
\text { untuk } \\
\text { lafadz أَبَتِتْنا }\end{array}$ & $\begin{array}{l}\text { Makhal } \\
\text { nasab }\end{array}$ & $\begin{array}{l}\text { Mabni } \\
\text { sukun }\end{array}$ & $\begin{array}{l}\text { Kam } \\
\text { khabariyyah }\end{array}$ \\
\hline مِن كُوِّ & $\begin{array}{l}\text { Tamyiz } \\
\text { Kam }\end{array}$ & $\begin{array}{l}\text { Makhal } \\
\text { nasab }\end{array}$ & & $\begin{array}{l}\text { Jer majrur } \\
\text { (mudhof mudof } \\
\text { ilaih) }\end{array}$ \\
\hline
\end{tabular}

Tabel. 11 menerangkan tentang bentuk dan kedudukan Kam dalam Qs. Ash-Shu'araa: 7. Lafadz Kam dalam ayat tersebut berbentuk Kam Khabariyyah yang ber-mahal nasab. Karena kedudukannya sebagai maf'ul bih dari lafadz أَنَبَتْنَ Lafadz tersebut terdiri dari fiil dan fail sehingga menjadi jumlah fi'liyyah. Tamyiz lafadz Kam pada ayat tersebut adalah بِن كُلِّ زَوْجِ . Lafadz tersebut terdiri dari huruf jer oِ dan mudhof mudhof ilaih yaitu كُّنِ زَوْنِ

Tabel. 12 (Surat Al-Qasas: 58)

\begin{tabular}{|c|c|c|c|c|}
\hline \multicolumn{5}{|c|}{ وَ كَمْ أَهْلَكْنَا مِن قَرَيَّةٍ بَطِرَتْ مَعِيشَتَهَا } \\
\hline Lafadz & Kedudukan & I'rab & $\begin{array}{c}\text { Alamat } \\
\text { I'rab }\end{array}$ & Keterangan \\
\hline كَمْ & $\begin{array}{l}\text { Maf'ul bih } \\
\text { lafadz } \\
\text { أَهْiَ' }\end{array}$ & $\begin{array}{l}\text { Makhal } \\
\text { nasab }\end{array}$ & $\begin{array}{l}\text { Mabni } \\
\text { sukun }\end{array}$ & $\begin{array}{l}\text { Kam } \\
\text { khabariyyah }\end{array}$ \\
\hline مِن قَرَيَّة & $\begin{array}{l}\text { tamyiz } \\
\text { Kam }\end{array}$ & $\begin{array}{l}\text { Makhal } \\
\text { nasab }\end{array}$ & & Jer majrur \\
\hline
\end{tabular}

Dalam tabel. 12 menjelaskan tentang bentuk dan kedudukan lafadz Kam pada Qs. Al-Qasas. Bentuk Kam pada ayat tersebut yaitu Kam khabariyyah. Kedudukan dari lafadz Kam tersebut yaitu sebagai maf'ul bih 
Muhammad Sayyidul Arwan \& Faizetul Ukhrawiyah: Bentuk dan Kedudukan Lafadz "Kam" Dalam Ayat-ayat Al Quran

dari jumlah fi'liyyah أَهَْْكْنَ Adapun I'rab lafadz Kam tersebut yaitu mahal nasab dengan tanda mabni sukun. Tamyiz lafadz Kam yaitu قِنَ قِيَّة yang berbentuk jer majrur.

Tabel. 13 (Surat As-Sajda: 26)

\begin{tabular}{|c|c|c|c|c|}
\hline Lafadz & Kedudukan & I'rab & $\begin{array}{c}\text { Alamat } \\
\text { I'rab }\end{array}$ & Keterangan \\
\hline كَمْ & $\begin{array}{l}\text { Maf'ul bih } \\
\text { lafadz } \\
\text { أَهْكَكْنَ }\end{array}$ & $\begin{array}{l}\text { Makhal } \\
\text { nasab }\end{array}$ & $\begin{array}{l}\text { Mabni } \\
\text { sukun }\end{array}$ & $\begin{array}{l}\text { Kam } \\
\text { khabariyyah }\end{array}$ \\
\hline
\end{tabular}

Tebel. 13 menjelasakan tentang bentuk dan kedudukan lafadz Kam pada ayat Qs. As-Sajda: 26. Bentuk Kam pada ayat tersebut adalah kam khabariyyah. Lafadz Kam tersebut berkedudukan maf'ul bih dari jumlah fi'liyyahi yaitu أَهْلَكْنْ . Adapun I'rab lafadz Kam tersebut adalah makhal nasab dengan tanda mabni sukun.

Tabel. 14 (Surat Yaseen: 31)

\begin{tabular}{|c|c|c|c|c|}
\hline \multicolumn{5}{|c|}{ 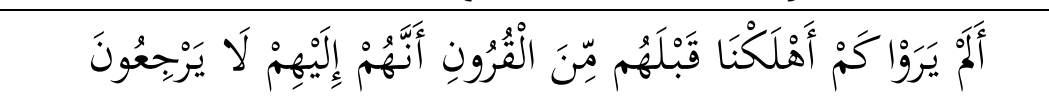 } \\
\hline Lafadz & Kedudukan & I'rab & $\begin{array}{c}\text { Alamat } \\
\text { I'rab }\end{array}$ & Keterangan \\
\hline كَمْ & 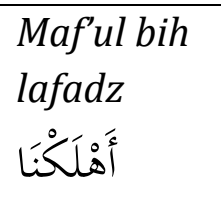 & $\begin{array}{l}\text { Makhal } \\
\text { nasab }\end{array}$ & $\begin{array}{l}\text { Mabni } \\
\text { sukun }\end{array}$ & $\begin{array}{l}\text { Kam } \\
\text { khabariyyah } \\
\text { Kam } \\
\text { istifhamiyyah }\end{array}$ \\
\hline
\end{tabular}

Tebel. 14 menjelasakan tentang bentuk dan kedudukan lafadz Kam pada ayat Qs. Yaseen: 31. Adapun bentuk Kam pada ayat tersebut memiliki dua bentu yaitu kam khabariyyah dan kam istifhamiyyah. Lafadz Kam tersebut

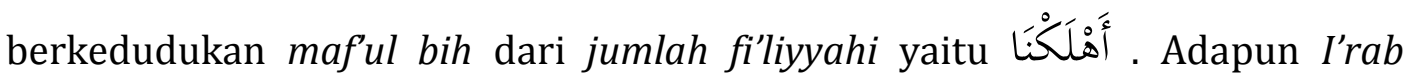
lafadz Kam tersebut adalah makhal nasab dengan tanda mabni sukun.

\section{Tabel. 15 (Surat Saad: 3)}


Muhammad Sayyidul Arwan \& Faizetul Ukhrawiyah: Bentuk dan Kedudukan Lafadz "Kam" Dalam Ayat-ayat Al Quran

\begin{tabular}{|c|c|c|c|c|}
\hline Lafadz & Kedudukan & I'rab & $\begin{array}{c}\text { Alamat } \\
\text { I'rab }\end{array}$ & Keterangan \\
\hline كَنْ & $\begin{array}{l}\text { Maf'ul bih } \\
\text { lafadz } \\
\text { أَهْلَكْنَأَ }\end{array}$ & $\begin{array}{l}\text { Makhal } \\
\text { nasab }\end{array}$ & $\begin{array}{l}\text { Mabni } \\
\text { sukun }\end{array}$ & $\begin{array}{l}\text { Kam } \\
\text { khabariyyah }\end{array}$ \\
\hline مِّنَ الْقُرُنَ & $\begin{array}{l}\text { Tamyiz } \\
\text { Kam }\end{array}$ & $\begin{array}{l}\text { Makhal } \\
\text { nasab }\end{array}$ & & Jer majrur \\
\hline
\end{tabular}

Dalam Tebel. 15 menjelasakan tentang bentuk dan kedudukan lafadz Kam pada ayat Qs. Saad: 3. Bentuk Kam pada ayat tersebut adalah kam khabariyyah. Adapun Kam tersebut berkedudukan menjadi maf'ul bih dari jumlah fi'liyyahi yaitu أَهْلَكْنَ I'rab lafadz Kam tersebut adalah makhal nasab

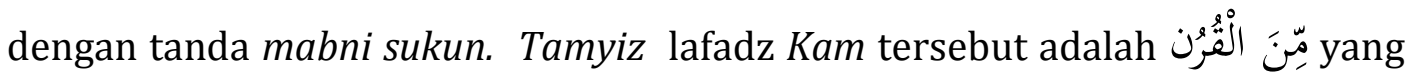
berbentuk jer majrur_ber-mahal nasab.

Tabel. 16 (Surat Az-Zukhruf: 6)

\begin{tabular}{|c|c|c|c|c|}
\hline \multicolumn{5}{|c|}{ 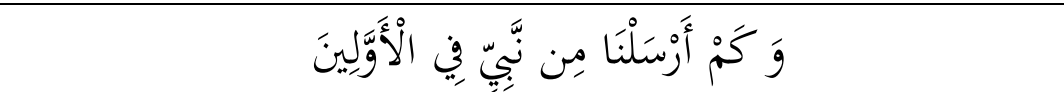 } \\
\hline Lafadz & Kedudukan & I'rab & $\begin{array}{c}\text { Alamat } \\
\text { I'rab }\end{array}$ & Keterangan \\
\hline كَنْ & $\begin{array}{l}\text { Maf'ul bih } \\
\text { lafadz } \\
\text { أَََََْْنًَا }\end{array}$ & $\begin{array}{l}\text { Makhal } \\
\text { nasab }\end{array}$ & $\begin{array}{l}\text { Mabni } \\
\text { sukun }\end{array}$ & $\begin{array}{l}\text { Kam } \\
\text { khabariyyah }\end{array}$ \\
\hline مِن نَبِّيّ & $\begin{array}{l}\text { Tamyiz } \\
\text { Kam }\end{array}$ & $\begin{array}{l}\text { Makhal } \\
\text { nasab }\end{array}$ & & Jer majrur \\
\hline
\end{tabular}

Dalam Tebel. 16 menjelasakan tentang bentuk dan kedudukan lafadz Kam pada ayat Qs. Az-Zukhruf: 6. Pada ayat tersebut lafadz Kam berbentuk kam khabariyyah. Adapun Kam tersebut berkedudukan menjadi maf'ul bih dari

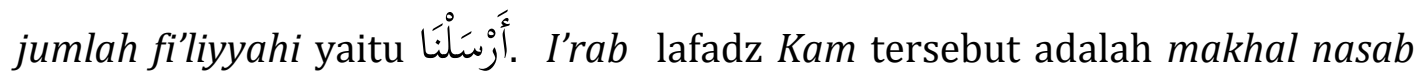


Muhammad Sayyidul Arwan \& Faizetul Ukhrawiyah: Bentuk dan Kedudukan Lafadz "Kam" Dalam Ayat-ayat Al Quran

dengan tanda mabni sukun. Tamyiz lafadz Kam tersebut adalah مَنَّبَّ yang berbentuk jer majrur_ber-mahal nasab.

Tabel. 17 (Surat Ad-Dukhaan: 25)

\begin{tabular}{|c|c|c|c|c|}
\hline \multicolumn{5}{|c|}{ كَمْ تَرَكُوا مِن جَنَّاتٍ وَعُعُوٍِ } \\
\hline Lafadz & Kedudukan & I'rab & $\begin{array}{c}\text { Alamat } \\
\text { I'rab }\end{array}$ & Keterangan \\
\hline كَمْ & $\begin{array}{l}\text { Maf'ul bih } \\
\text { untuk } \\
\text { lafadz تَرَكُوا lafl }\end{array}$ & $\begin{array}{l}\text { Makhal } \\
\text { nasab }\end{array}$ & $\begin{array}{l}\text { Mabni } \\
\text { sukun }\end{array}$ & $\begin{array}{l}\text { Kam } \\
\text { khabariyyah }\end{array}$ \\
\hline
\end{tabular}

Tebel. 17 menjelasakan tentang bentuk lafadz Kam beserta kedudukannya lafadz Kam pada ayat Qs.Ad-Dukhaan: 25. Pada ayat tersebut lafadz Kam berbentuk kam khabariyyah. Adapun Kam tersebut berkedudukan menjadi maf'ul bih dari jumlah fi'liyyahi yaitu تَرَكُوا. Adapun I'rab lafadz Kam tersebut adalah makhal nasab dengan tanda mabni sukun.

Tabel. 18 (Surat Qaaf: 36)

\begin{tabular}{|c|c|c|c|c|}
\hline \multicolumn{5}{|c|}{ 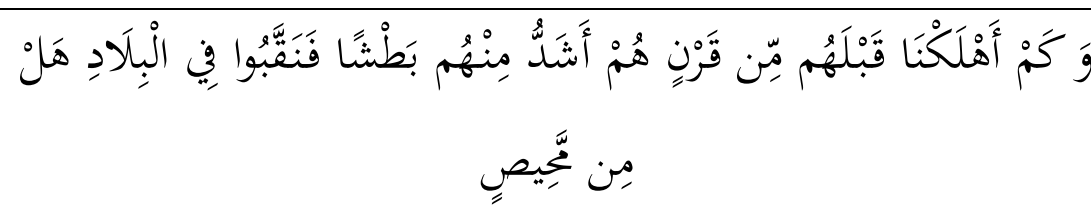 } \\
\hline Lafadz & Kedudukan & I'rab & $\begin{array}{c}\text { Alamat } \\
\text { I'rab }\end{array}$ & Keterangan \\
\hline كَمْ & 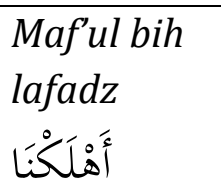 & $\begin{array}{l}\text { Makhal } \\
\text { nasab }\end{array}$ & $\begin{array}{l}\text { Mabni } \\
\text { sukun }\end{array}$ & $\begin{array}{l}\text { Kam } \\
\text { khabariyyah }\end{array}$ \\
\hline 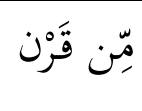 & $\begin{array}{l}\text { Tamyiz } \\
\text { Kam }\end{array}$ & $\begin{array}{l}\text { Makhal } \\
\text { nasab }\end{array}$ & & Jer majrur \\
\hline
\end{tabular}

Dalam table. 18 menjelaskan tentang bentuk dan kedudukan lafadz Kam yang terdapat dalam Qs. Qaaf: 36. Bentuk lafadz Kam pada ayat tersebut adalah kam khabariyyah. Adapun kedudukannya yaitu menjadi maf'ul bih dari lafadz أَهَْكْنْ yang berbentuk jumlah fi'liyyah. Tamyiz lafadz Kam tersebut 
Muhammad Sayyidul Arwan \& Faizetul Ukhrawiyah: Bentuk dan Kedudukan Lafadz "Kam" Dalam Ayat-ayat Al Quran

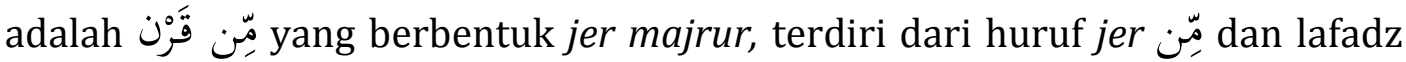
yang dibaca jer قَرَّن.

\section{Pengganti Dhorof}

Lafadz Kam berkedudukan menjadi pengganti dhorof berI'rab makhal nasab dan beralamat mabni sukun. Ayat-ayat Al Quran yang berkedudukan sebagai pengganti dhorof, sebagai berikut: Surat Al-Baqoroh, Ayat 259, Surat Al-Kahf Ayat 19, dan Surat Al-Muminoon Ayat 112.

Tabel. 19 (Surat Al-Baqoroh: 259)

\begin{tabular}{|c|c|c|c|c|}
\hline \multicolumn{5}{|c|}{ 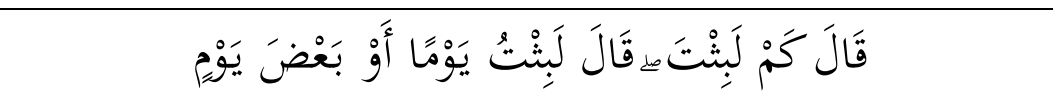 } \\
\hline Lafadz & Kedudukan & $I^{\prime} r a b$ & $\begin{array}{c}\text { Alamat } \\
\text { I'rab }\end{array}$ & Keterangan \\
\hline كَمْ & $\begin{array}{l}\text { Pengganti } \\
\text { dhorof } \\
\text { Tamyiznya } \\
\text { dibuang } \\
\text { yaitu } \\
\text { lafadz }\end{array}$ & $\begin{array}{l}\text { Makhal } \\
\text { nasab }\end{array}$ & $\begin{array}{l}\text { Mabni } \\
\text { sukun }\end{array}$ & Kam istifham \\
\hline لَبشْتَ & $\begin{array}{l}\text { Maf'ul bih } \\
\text { dari lafadz } \\
\text { قَال }\end{array}$ & $\begin{array}{l}\text { Makhal } \\
\text { nasab }\end{array}$ & & $\begin{array}{l}\text { Jumlah } \\
\text { fi'liyyah }\end{array}$ \\
\hline
\end{tabular}

Tabel. 19 menjelaskan tentang bentuk dan kedudukan lafadz Kam dalam Qs. Al-Baqoroh: 259. Lafadz Kam pada ayat tersebut berbentuk kam istifhamiyyah yang berfungsi sebagai pertanyaan. Kedudukan Kam dalam ayat tersebut sebagai pengganti dhorof atau keterangan. Tamyiz lafadz Kam dalam ayat tersebuat adalah lafadz يَوَ yang dibuang dari susunan. Adapun redaksi ketika tamyiz tidak dibuang menjadi يَوْمَا كَمْ لَبَتْتَ

Tabel. 20 (Surat Al-Kahf : 19) 
Muhammad Sayyidul Arwan \& Faizetul Ukhrawiyah: Bentuk dan Kedudukan Lafadz “Kam” Dalam Ayat-ayat Al Quran

\begin{tabular}{|c|c|c|c|c|}
\hline \multicolumn{5}{|c|}{ 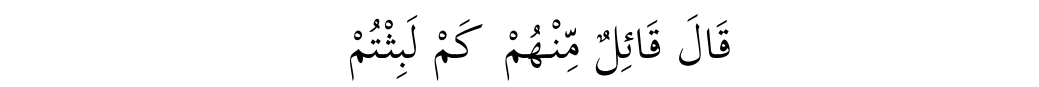 } \\
\hline lafadz & Kedudukan & I'rab & $\begin{array}{c}\text { Alamat } \\
\text { I'rab }\end{array}$ & Keterangan \\
\hline كَمْ & $\begin{array}{l}\text { Pengganti } \\
\text { dhorof. } \\
\text { Tamyiz } \\
\text { terbuang } \\
\text { yaitu } \\
\text { lafadz }\end{array}$ & $\begin{array}{l}\text { Makhal } \\
\text { nasab }\end{array}$ & $\begin{array}{l}\text { Mabni } \\
\text { sukun }\end{array}$ & $\begin{array}{l}\text { Kam } \\
\text { istifhamiyyah }\end{array}$ \\
\hline
\end{tabular}

Dalam table. 20 menjelaskan tentang bentuk dan kedudukan Kam dalam Qs. Al-Kahf: 19. Bentuk lafadz Kam pada ayat tersebut berbentuk kam istifhamiyyah yang berarti "berapa". Adapun kedudukannya menjadi pengganti dhorof dengan terbuangnya tamyiz yaitu lafadz يَوْمًا. I'rab lafadz kam ber-makhal nasab dengan alamat mabni sukun.

Tabel. 21 (Surat Al-Mu'minūn: 112)

\begin{tabular}{|c|c|c|c|c|}
\hline \multicolumn{5}{|c|}{ 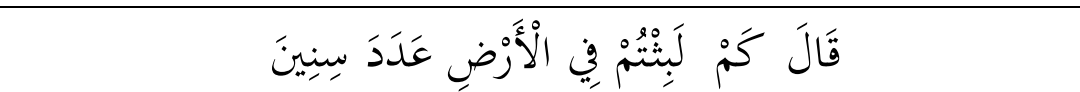 } \\
\hline lafadz & Kedudukan & I'rab & $\begin{array}{c}\text { Alamat } \\
\text { I'rab }\end{array}$ & Keterangan \\
\hline كَمْ & $\begin{array}{l}\text { Pengganti } \\
\text { dhorof. }\end{array}$ & $\begin{array}{l}\text { Makhal } \\
\text { nasab }\end{array}$ & $\begin{array}{l}\text { Mabni } \\
\text { sukun }\end{array}$ & $\begin{array}{l}\text { Kam } \\
\text { istifhamiyyah }\end{array}$ \\
\hline عَدِنَدَ & $\begin{array}{l}\text { Tamyiz } \\
\text { Kam }\end{array}$ & Nasab & Fathah & $\begin{array}{l}\text { Mudhof dan } \\
\text { mudhof ilaih }\end{array}$ \\
\hline
\end{tabular}

Table. 21 menjelasakan bentuk Kam dan kedudukannya pada ayat 112 Qs. Al-Mu'minun. Bentuk Kam dalam ayat tersebut adalah kam istifhamiyyah atau kam yang berfungsi sebagai pertanyaan. Adapun keududukan Kam pada ayat tersebut yaitu sebagai pengganti dhorof, dengan mahal nasab yang beralamat mabni sukun. Tamyiz lafadz Kam pada ayat tersebut adalah lafadz yang berbentuk susunan idhofah yaitu mudhof dan mudhof ilaih. 
Muhammad Sayyidul Arwan \& Faizetul Ukhrawiyah: Bentuk dan Kedudukan Lafadz "Kam" Dalam Ayat-ayat Al Quran

\section{SIMPULAN}

Pembahasan pada penelitian ini tentang bentuk-bentuk lafadz Kam pada Al Quran, berseta kedudukan lafadz Kam pada ayat-ayat Al Quran, dengan kesimpulan:

Bentuk lafadz Kam dalam Al Quran memiliki dua bentuk; Pertama, berbentuk "Kam Istifhamiyyah" yang terdapat pada terdapat pada ayat-ayat sebagai berikut: Surat Al-Baqarah Ayat 211 dan 259, Surat Al-An'ām Ayat 6, Surat Al-Kahf Ayat 19, Surat Al-Mu'minūn Ayat 112, dan Surat Yaseen Ayat 31. Kedua, bentuk "Kam Khobariyya" terdapat pada ayat-ayat sebagai berikut: Surat Al-Baqarah Ayat 249, Surat Al-An'am Ayat 6, Surat Al-A'rāf Ayat 4, Surat Al-Isrā Ayat 17, Surat Maryam Ayat 74, Surat Maryam Ayat 98, Surat Tã-Hā Ayat 128, Surat Al-Anbiyā Ayat 11, Surat Al Shu'arā Ayat 7, Surat Al-Qasas Ayat 58, Surat Al-Sajdah Ayat 26, Surat Yasîn Ayat 31, Surat Saad Ayat 3, Surat AzZukhruf Ayat 6, Surat Ad-Dukhān Ayat 25, Surat Qaaf Ayat 36, dan Surat AnNajm Ayat 26. Ketiga, lafadz Kam yang memiliki dua bentuk antara "Kam Istifhamiyyah" dan "Kam Khobariyya" terdapat pada Surat Al-An'ām Ayat 6 dan Surat Yasîn Ayat 31.

Kedudukan lafadz Kam didalam ayat-ayat Al Quran terdapat pada tiga kedudukan, yaitu Mubtada', Maf'ul bih dan Pengganti Dhorof. Pertama, Sebagai Mubtada' terdapat pada ayat-ayat sebagai berikut: Surat Al-Baqoroh, Ayat 249, Surat Al-A'räf, Ayat 4, dan Surat An-Najm, Ayat 26. Kedua, Sebagai maf'ul bih terdapat pada ayat-ayat sebagai berikut: Surat Al-Baqoroh Ayat 211, Surat AlAn'am Ayat 6, Surat Al-Isrā Ayat 17, Surat Maryam Ayat 74, Surat Maryam Ayat 98, Surat Tã-Hā Ayat 128, Surat Al-Ambiyaa Ayat 11, Surat Al Shu'arā Ayat 7, Surat Al-Qasas Ayat 58, Surat Al-Sajda Ayat 26, Surat Yaseen Ayat 31, Surat Saad Ayat 3, Surat Az-Zukhruf Ayat 6, Surat Ad-Dukhān Ayat 25, dan Surat Qaaf Ayat 36. Ketiga, Sebagi pengganti dhorof terdapat pada ayat-ayat sebagai berikut: Surat Al-Baqoroh, Ayat 259, Surat Al-Kahf Ayat 19, dan Surat AlMu'minūn Ayat 112.

\section{Daftar Pustaka}

Al-Khotib, Thohir Yusuf. Al-Mu'jam Al-Mufashol fi Ai-I'rob. Sangqopurah: AlHaromin, 1991.

Aplikasi Ayat-Ayat. King Saud University, t.t.

Bakar, Bahrun Abu. Terjemahan Alfiyah Syarah Ibnu 'Aqil. Bandung: Penerbit Sinar Baru Algensindo, 2013.

Chaer, Abdul. Linguistik Umum. Jakarta: PT Rineka Cipta, 2012.

Hasan, Hasan, Penerjemahan Arab Indonesia Antara Bahasa dan Budaya Banjarbaru: Atap Buku, 2017. 
Muhammad Sayyidul Arwan \& Faizetul Ukhrawiyah: Bentuk dan Kedudukan Lafadz "Kam" Dalam Ayat-ayat Al Quran

Hakim, Arif Rahman. "Mempermudah Pembelajaran Ilmu Nahwu pada abad 20." Jurnal al-Maqoyis 1, no. 1 (t.t.): 1-26.

Haris, Abdul. Cepat Membaca Kitab Gundul: Teknik 234, t.t.

Hidayat, Syamsul, dan Amien Ashiddiqi. "METODE I'R $\bar{A} B$ AL QURAN DAN KONVENSIONAL SEBAGAI PEMBELAJARAN BAHASA ARAB BAGI NON ARAB DI PONPES AL MADINAH BOYOLALI." Profetika Jurnal Studi Islam 19, no. 2 (15 Mei 2019): https://doi.org/10.23917/profetika.v19i2.8119.

Husin, Husin, dan Hatmiati Hatmiati. "BUDAYA DALAM PENERJEMAHAN BAHASA." Al Mi'yar: Jurnal Ilmiah Pembelajaran Bahasa Arab dan Kebahasaaraban 1, no. 2 (14 Oktober 2018) https://doi.org/10.35931/am.v1i2.43.

Jauhari, Muhammad Idris. Al-Qawaid as-Sharfiyah. Sumenep: Mutiara Press, 2016.

Kholison, Mohammad. Semantik Bahasa Arab: Tinjauan Historis, Teoritik, dan Aplikatif. Sidoarjo: CV Lisan Arabi, 2016.

Rikabi, Jaudat. Turuqu Tadris al-Lughah al-'Arabiyah. Damaskus: Dar al-Fikr, 1996.

Ya'qub, Imil Badi', dan Misal Asy. Al-Mu'jam Al-Mufashol fi Al-Lighoh wa AlAdab. Bairut: Darul Ilmi Lil Malayin, t.t.

Yunus, Muhammad. Kamus Arab-Indonesia. Jakarta: PT. Hidakarya Agung, 1990. 
Muhammad Sayyidul Arwan \& Faizetul Ukhrawiyah: Bentuk dan Kedudukan Lafadz "Kam" Dalam Ayat-ayat Al Quran 